\title{
A Note on The Volatility of the Tradeable and Nontradeable Sectors
}

\author{
Laura Povoledo* \\ University of the West of England ${ }^{\dagger}$
}

${ }^{*}$ I would like to thank Luca Benati, Gianluca Benigno, Fabio Canova, Wendy Carlin, Huw Dixon, Nils Gottfries, Peter Howells, Vincent Labhard, Kerry Patterson, Christoph Schleicher and Gianluca Violante for useful comments and advice. I also thank seminar participants at the Bank of England, Durham University, University of Loughborough, Universidad del País Vasco, University of Sydney, Uppsala University, CDMA conference in St. Andrews, the 2nd Mannheim conference Recent Developments in Macroeconomics and the EEA for their comments and discussions. Any errors or shortcomings are my sole responsibility.

${ }^{\dagger}$ Coldharbour Lane, Bristol BS16 $\quad$ 1QY $\quad$ (UK). Tel: $0044 \quad 117 \quad 32 \quad 83454 . \quad$ Email: Laura.Povoledo@uwe.ac.uk. 


\begin{abstract}
This note evaluates whether a "New Open Economy" model can reproduce qualitatively the observed fluctuations of the tradeable and nontradeable sectors of the US economy. The answer is positive: both in the model and in the data the standard deviations of tradeable inflation, output and employment are significantly higher than the standard deviations of the corresponding nontradeable sector variables. The key role in generating this result is played by the greater responsiveness of tradeable sector variables to monetary shocks.
\end{abstract}

\title{
JEL classification: F41; E32
}

Keywords: New Open Economy Macroeconomics; Tradeable and Nontradeable Sectors; Business Cycles. 


\section{Introduction}

In the field of international macroeconomics there are now many models that explicitly consider two sectors, one producing tradeable and the other producing nontradeable goods. However, the strategy of adding a tradeable and a nontradeable sector to an open economy model is not without problems. It is important, for example, to check whether the model-generated statistics are consistent with the sectoral data. ${ }^{1}$

The purpose of this note is to develop an open economy model with tradeables and nontradeables, estimate it by the Generalised Method of Moments (GMM), and then check whether its implications for the tradeable and nontradeable sectors are reflected in the US data. The model presented in this paper follows the "New Open Economy Macroeconomics" (NOEM) paradigm, and the comparison between the data and the model is restricted to second-order moments.

After the initial contributions of Ghironi (2000), Bergin (2003), and Lubik and Schorfheide (2005), the literature on estimating NOEM models has grown considerably in recent years. More recent contributions include (with no claim of being ex-

\footnotetext{
${ }^{1}$ For example, Barsky, House and Kimball (2007) note that durable goods feature prominently in discussions of monetary policy. Conventional sticky-price models with durables must be able to match not only the central features of the data, but also the empirical properties of the durable and nondurable goods sectors. Barsky, House and Kimball (2007) show that this not the case, and suggest adding additional features to conventional sticky-price models.

A similar issue arises for nontradeable goods. They feature prominently in new open economy models and have been shown to increase the models' ability to match central features of the data. But is a conventional NOEM model also able to match the basic properties of the tradeable and nontradeable sectors? This paper shows that the answer is yes.
} 
haustive), Lubik and Schorfheide (2007), Justiniano and Preston (2010a and 2010b), and Rabanal and Tuesta (2010). This paper differs from other contributions not just because of the estimation methodology, ${ }^{2}$ but because of the goal of the investigation, which is to compare the properties of the tradeable and nontradeable sectors in the model and in the US data.

However, this sort of analysis is hampered by a measurement problem. The properties of the tradeable and nontradeable sectors can only be imperfectly measured, since virtually all sectors (as measured in the official statistics) have both tradeable and nontradeable goods. ${ }^{3}$ The strategy adopted here to deal with this problem is to restrict ourselves to qualitative, rather than quantitative, comparisons.

In spite of the measurement problem in the data, there is sufficient evidence to suggest that in the US economy business cycle fluctuations are more pronounced in the tradeable than in the nontradeable sector. When the NOEM model is fed with the estimated values, it is successful in generating standard deviations of tradeable inflation, output and employment that are considerably higher than the standard deviations of the corresponding nontradeable sector variables. This occurs because of the high responsiveness of tradeable sector variables to domestic monetary shocks, which are the most important source of fluctuations in the model.

The outline of the remainder of the note is as follows. Section 2 explains the model

\footnotetext{
${ }^{2}$ Ghironi (2000) estimates a NOEM by nonlinear least squares at the single-equation level and FIML system-wide regressions. Bergin (2003) uses maximum likelihood techniques. Lubik and Schorfheide (2005 and 2007), Justiniano and Preston (2010a and 2010b), and Rabanal and Tuesta (2010) use Bayesian methods.

${ }^{3}$ Conceptually it is possible to divide goods into tradeables and nontradeables, but disaggregated macroeconomic data, if available, is only for sectors as defined in the statistics.
} 
and its numerical solution. The estimation and calibration of the model are explained in Section 3. The model-implied statistics are presented in Section 4. Sensitivity checks are discussed in Section 5. Finally, Section 6 concludes.

\section{The model}

The model is similar to Benigno and Thoenissen's (2003). ${ }^{4}$ Here I outline the main features of the model, and I specify the assumptions that are different from Benigno and Thoenissen's model.

The world economy consists of two countries of equal size, named Home and Foreign. Each country has a tradeable and a nontradeable sector. Both sectors are populated by a continuum of monopolistic firms, each one of them producing a single differentiated good for final consumption.

Individuals cannot contemporaneously supply their labour to both the tradeable and nontradeable goods sectors, as they can only work in one sector at a time. Any individual who works incurs a fixed participation cost, as in Burnside, Eichenbaum and Rebelo (1993).

Following Rogerson (1988), I add the probabilities of working in each sector to the individual maximization problem. That is, the utility of a representative individual in the Home country is written as follows:

$$
U_{0}=E_{0} \sum_{t=0}^{\infty} \beta^{t}\left[\begin{array}{c}
\frac{C_{t}^{1-\sigma}-1}{1-\sigma}+\frac{\chi}{1-\varepsilon}\left(\frac{M_{t}}{P_{t}}\right)^{1-\varepsilon}+n_{T H, t} \cdot \kappa\left(\Gamma-\psi-\mathbf{h}_{T H, t}\right) \\
+n_{N, t} \cdot \kappa\left(\Gamma-\psi-\mathbf{h}_{N, t}\right) \\
+\left(1-n_{T H, t}-n_{N, t}\right) \cdot \kappa(\tau)
\end{array}\right],
$$

\footnotetext{
${ }^{4}$ Detailed derivations of all the equations are available from the author on request.
} 
where $C$ is the aggregate consumption index, $\frac{M}{P}$ are real money balances, $n_{T H}, n_{N}$ are the probabilities of working in the tradeable and nontradeable sector respectively, $\psi$ is a fixed cost of participation, the same for all individuals, ${ }^{5}$ and $\mathbf{h}_{T H}$ and $\mathbf{h}_{N}$ are the total hours that the individual supplies to the sectors $T H$ and $N$ respectively. Preferences over goods are described by CES aggregators.

At the international level, markets are incomplete: individuals trade in a oneperiod non-contingent real bond, denominated in units of the Home tradeable goods consumption index. Similarly to Benigno (2009), individuals must pay a small cost in order to undertake a position in the international asset market.

Nominal rigidities are introduced à la Calvo (1983). Tradeable goods firms in both countries set two different prices, one for the Home market and one for the Foreign market, denominated in the respective local currencies. A positive parameter governs the degree of exchange rate pass-through into import prices, as in Corsetti and Pesenti (2005). Output sold at Home and abroad is produced using a common plant or production function.

The model includes government expenditure shocks, and specifies monetary policy in terms of the growth rate of money (as in Chari, Kehoe and McGrattan, 2002). I assume that the Home and Foreign governments purchase only nontradeable goods ${ }^{6}$ produced in their own country. The money growth rates, government expenditures,

\footnotetext{
${ }^{5}$ Total time available is different for the employed $(\Gamma)$ and the unemployed $(\tau)$.

${ }^{6}$ According to the Bureau of Economic Analysis' "Guide to the National Income and Product Accounts of the United States", government expenditure essentially consists of services provided to the public free of charge. Goods (and services) that are sold by the government are instead classified as personal consumption expenditure (if purchased by individuals), or intermediate inputs (if purchased by businesses).
} 
and the growth rates of technology for each country and sector follow AR(1) processes.

Preferences and functional forms used to describe the Home and Foreign countries are the same. Tables 1 and 2 illustrate which parameters are (and which ones are not) assumed to be the same for both countries.

The model is solved by log-linearising the equations around a deterministic equilibrium or steady state in which net foreign asset positions are normalised at zero. The resulting system is then solved using Uhlig's "Toolkit" algorithm (1999). The shocks to the $\mathrm{AR}(1)$ processes are all assumed to be temporary.

The unconditional means of the productivity processes are calibrated so as to ensure that the steady state of the model reproduces three facts in the data: the ratios of tradeable to nontradeable output in the two countries, and the ratio of Home to Foreign tradeable output. These ratios are computed using year-2000 data from the Groningen 60-Industry Database. ${ }^{7}$

An important feature of the solution is that hours are always endogenously constant. As a result, all the adjustment in the labour inputs takes place through the extensive margin, i.e. the participation rates or probabilities. ${ }^{8}$

\section{Estimation}

The sample period is 1980:1 to 2007:4. The Home country is represented by the US, and the Foreign country by an aggregate of its major trading partners. The latter

\footnotetext{
${ }^{7}$ Groningen Growth and Development Centre, 60-Industry Database, February 2005, http://www.ggdc.net. Since the year 2000 is the base year of the Groningen dataset, the data for the year 2000 does not depend on the computation of output deflators.

${ }^{8}$ See Povoledo (2010) for a clarification on this point.
} 
comprises Canada, France, Germany, ${ }^{9}$ Japan, Mexico and the UK, which together represented $46 \%$ of the US total trade in goods in 2007. The combined GDP of these six countries was 104\% of the US GDP in the last quarter of 2007.

The tradeable sector is represented by manufacturing, and the nontradeable sector by services. ${ }^{10}$ This approximation is advantageous because quarterly observations on output, prices and employment levels are available, and it is consistent with standard assumptions in the literature.

Not all of the model parameters could be estimated by GMM, as in some cases identification problems occurred during estimation. ${ }^{11}$ Table 1 shows the parameters that have not been estimated by GMM but instead have been chosen according to suggestions made in the literature. ${ }^{12}$ I check the robustness of the results of Section 4 to changes in all the parameters of Table 1 . The most interesting of these sensitivity checks can be found in Table 6 .

\section{TABLE 1 HERE}

The preference weights $\gamma$ and $\delta$ are calibrated so that the steady-state import and service shares in consumption are consistent with the US data, ${ }^{13}$ and $\delta^{*}$ is set equal to $1-\delta$. The benchmark value for the elasticity of substitution $\theta$ between Home

\footnotetext{
${ }^{9}$ East Germany is not included in the time series up until 1990:4.

${ }^{10}$ Notice that only goods can be durable or nondurable, while services are neither durable nor nondurable.

${ }^{11}$ The GMM estimation delivers the same estimates as OLS and SUR.

${ }^{12}$ The specification of the functional form $\kappa$ and the calibration of the parameters $\chi, \Gamma, \tau$ and $\psi$ are irrelevant for the solution.

${ }^{13}$ That is, the ratio of imports of goods over total expenditure for goods (equal to 0.35), and the share of services in total (tradeable and nontradeable) consumption (equal to 0.56).
} 
and Foreign tradeables is taken from Obstfeld and Rogoff (2005). The values for $\eta_{T}$ and $\eta_{N}$ are those suggested by Faruqee, Laxton, Muir and Pesenti (2005) for the US economy. I use the short-run elasticities of exchange rate pass-through into import prices estimated by Campa and Goldberg (2005) to parameterize $\zeta$ and $\zeta^{*}{ }^{14}$ Finally, $\alpha_{T}$ and $\alpha_{N}$ are chosen so as to match the labour shares in value added in the US manufacturing and service sectors. ${ }^{15}$

The moment conditions ${ }^{16}$ are derived from the log-linearised solution (as in Ghironi 2000), and have been estimated using logged, seasonally adjusted and HP-filtered data. The estimated parameters are presented in Table 2. Because of the small size of the sample, I estimate the parameters using an exactly identified system. ${ }^{17}$

\section{TABLE 2 HERE}

\section{Results}

Table 3 reports the main business cycle statistics for the model. Tables 4 and 5 report the sectoral data moments and the sectoral model moments.

\section{TABLE 3 HERE}

\footnotetext{
${ }^{14}$ Specifically, $\zeta$ is their estimated value for the US, and $\zeta^{*}$ is a weighted average of their estimates for Canada, France, Germany, Japan and the UK.

${ }^{15}$ These are equal to 0.64 and 0.56 respectively.

${ }^{16}$ Detailed appendices illustrating the derivation of the moment conditions and the construction of the data variables are available from the author on request.

${ }^{17}$ I compute the optimal weighting matrix using the Newey and West (1987) estimator with a Bartlett kernel. I have also verified that the estimates are not significantly affected by the choice of kernel or lag length.
} 


\section{TABLE 4 HERE}

\section{TABLE 5 HERE}

By identifying the tradeable sector with manufacturing we neglect agriculture or mining, and by identifying the nontradeable sector with the service sector we include also services that are actually traded. ${ }^{18}$ Since the measurement problem also affects the performance of the model with respect to the sectoral data, I restrict the comparison between the data and the model's statistics to being qualitative in nature rather than quantitative. ${ }^{19}$

Overall, the estimated model generates standard deviations of tradeable inflation, output and employment that are considerably higher than the standard deviations of the corresponding nontradeable sector variables. Moreover, the cross correlations are all positive, as in the data.

The main cause of the higher volatility in the tradeable sector is its higher sensitivity to Home monetary shocks. ${ }^{20}$ In the model, prices, output and employment

\footnotetext{
${ }^{18}$ For the US, it is possible to obtain data on more sectors, but only at the annual frequency. In Povoledo (2010) I report standard deviations computed using such data, which confirm that the standard deviations in the tradeable sectors are higher than the standard deviations in the nontradeable sectors.

${ }^{19}$ However, this measurement problem does not affect equally all the estimated values, for example, it does not affect the variance of the monetary shocks. This consideration confirms that the comparison between the data and the model-generated statistics cannot be strictly quantitative.

${ }^{20}$ In Povoledo (2010) I perform a variance decomposition exercise and I show that Home monetary shocks are by far the most important source of fluctuations of sector-specific inflation rates and output levels. This is true also for sector-specific employment levels, but the latter
} 
levels all increase after a positive Home monetary shock, ${ }^{21}$ but they increase more in the tradeable sector than in the nontradeable sector. This happens because the same channels which ensure the international transmission of shocks also amplify the responses of tradeable sector variables to domestic monetary shocks. ${ }^{22}$

Let us consider first sectoral output levels. A positive Home monetary shock causes a terms of trade deterioration, a fall in the real interest rate and an increase in Home bond holdings. The terms of trade deterioration may or may not cause tradeable output to respond more ${ }^{23}$ but the increase in bond holdings always causes tradeable output to increase more than nontradeable output after a monetary shock, thus explaining the higher volatility. The rationale is that borrowing allows the Foreign country to increase its consumption via the asset market, as a result, there is more demand for Home exports.

are also significantly influenced by Home technology shocks.

${ }^{21}$ This is a standard result, common to both the producer currency pricing model of Obstfeld and Rogoff (1995) and the local currency pricing model of Betts and Devereaux (2000). Impulse responses of all variables are available from the author on request.

${ }^{22}$ In Povoledo (2010) I present a system of three equations that illustrates the key variables or channels of transmission of the exogenous shocks to the ratios of tradeable to nontradeable prices, output and employment. This system shows that the same channels which ensure the international transmission of shocks (the nominal exchange rate, the terms of trade and the asset market) amplify the responses of tradeable sector variables to domestic monetary shocks.

${ }^{23}$ This depends on the size of the elasticity of substitution between tradeable and nontradeable goods. 
Next, let us consider sectoral inflation rates. Even if the degree of price stickiness is the same, tradeable inflation increases more than nontradeable output after a positive monetary shocks. The key is the nominal exchange rate depreciation: because there is imperfect pass-through, the Foreign currency revenues of Home firms increase, so the tradeable price index increases. ${ }^{24}$

Finally, since tradeable output responds more to Home monetary shocks, then the firms' demand for the labour input has to respond more too. Moreover, Home productivity shocks are significantly more volatile in the tradeable sector than in the nontradeable sector. This explains the higher volatility of employment in the tradeable sector.

\section{Sensitivity analysis}

By checking whether the results are sensitive to some of the parametrized values, we can further investigate the properties of the NOEM model. Table 6 shows the modelimplied standard deviations obtained under three different parametrizations: a lower elasticity of substitution Home-Foreign tradeables, a higher share of non-domestic goods in the tradeable consumption basket, and a lower degree of price rigidity in the tradeable sector. Under all these alternative assumptions, tradeable sector variables are still more volatile than nontradeable sector variables.

\section{TABLE 6 HERE}

\footnotetext{
${ }^{24}$ I define the price index for all Home tradeable goods as a weighted average of the price of output sold at Home and the price of output sold to Foreign consumers, converted in Home currency.
} 
Table 6 also considers the two extreme assumptions of local currency pricing (LCP) and producer currency pricing (PCP). ${ }^{25}$ Under LCP, if the exchange rate depreciates following a monetary shock, Home firms get more domestic currency for each unit of output sold abroad. As a result, the tradeable price index responds more to domestic monetary shocks and the standard deviation of tradeable inflation is higher. Moreover, under LCP if the nominal exchange rate depreciates the terms of trade falls (appreciates) strongly. This depresses the Foreign demand for Home tradeable output, which therefore responds less after a monetary shock. At the other extreme, under PCP, if the exchange rate depreciates following a monetary shock, the terms of trade increases, boosting the Foreign demand for Home tradeable output. Moreover, under PCP the exchange rate does not affect the price that Home firms get for each unit of output sold abroad.

To analyse the complete markets case I have developed a separate version of the model, and I have conducted simulations using the same parameters as in the baseline parametrisation. In Section 4, I explained that after a positive Home monetary shock Foreign households increase their consumption via borrowing, so Home exports increase. This explains why tradeable output is more volatile than nontradeable output. This effect exists under complete markets too, but it does not operate via debt, but via trade in state-contingent assets.

Finally, I have also checked whether the results from the model are robust to the introduction of aggregate productivity shocks. This scenario can be investigated by assuming that the tradeable and nontradeable productivity shocks are perfectly correlated. The last row of Table 6 shows that this assumption does not alter the

\footnotetext{
${ }^{25}$ Under LCP, the pass-through elasticities $\zeta$ and $\zeta^{*}$ are equal to zero, and under PCP the pass-through elasticities $\zeta$ and $\zeta^{*}$ are equal to one.
} 
main qualitative result, but there is an increase in the standard deviations of tradeable output and tradeable employment.

\section{Conclusion}

This note has developed and estimated by GMM a new open economy model, with the purpose of analysing the fluctuations of the tradeable and nontradeable sectors.

The estimated model generates standard deviations that are compatible, from a qualitative point of view, with the pattern observed in the data. In the data, the standard deviations of inflation, output and employment are higher in the tradeable sector than in the nontradeable sector. The model shows that this happens because of the greater responsiveness of tradeable sector variables to monetary shocks. 


\section{References}

Barsky, Robert B., Christopher L. House, and Miles S. Kimball (2007) StickyPrice Models and Durable Goods. American Economic Review 97:3, 984-998.

Benigno, Gianluca, and Christoph Thoenissen (2003) Equilibrium Exchange Rates and UK Supply Side Performance. Economic Journal 113, 103-124.

Benigno, Pierpaolo (2009) Price Stability with Imperfect Financial Integration. Journal of Money, Credit and Banking 41, 121-149.

Bergin, Paul R (2003) Putting the 'New Open Economy Macroeconomics' to a test. Journal of International Economics 60, 3-34.

Betts, Caroline, and Michael B. Devereux (2000) Exchange Rate Dynamics in a Model of Pricing to Market. Journal of International Economics 50, 215-244.

Burnside, Craig, Martin Eichenbaum, and Sergio Rebelo (1993) Labor Hoarding and the Business Cycle. Journal of Political Economy 101:2, 245-273.

Calvo, Guillermo A. (1993) Staggered Prices in a Utility-Maximising Framework. Journal of Monetary Economics 12:3, 383-398.

Campa, José Manuel, and Linda S. Goldberg (2005) Exchange Rate Pass-Through into Import Prices. The Review of Economics and Statistics 87:4, 679-690.

Canova, Fabio (2007) Methods for Applied Macroeconomics Research. Princeton: Princeton University Press.

Chari, V. V., Patrick J. Kehoe, and Ellen R. McGrattan (2002) Can Sticky Price Models Generate Volatile and Persistent Real Exchange Rates? Review of Economic Studies 69:3, 533-63.

Corsetti, Giancarlo, and Paolo Pesenti (2005) International dimensions of optimal monetary policy. Journal of Monetary Economics 52:2, 281-305.

Faruqee, Hamid, Douglas Laxton, Dirk Muir, and Paolo Pesenti (2005) Smooth 
Landing or Crash? Model-Based Scenarios of Global Current Account Rebalancing. NBER Working Papers 11583, National Bureau of Economic Research.

Ghironi, Fabio (2000) Towards new open economy macroeconometrics. Federal Reserve Bank of New York, Staff Reports No. 100.

Hodrick, Robert J., and Edward C. Prescott (1997) Postwar U.S. Business Cycles: An Empirical Investigation. Journal of Money, Credit, and Banking 29, 1-16.

Justiniano, Alejandro, and Bruce Preston (2010a) Can structural small openeconomy models account for the influence of foreign disturbances? Journal of International Economics 81:1, 61-74.

Justiniano, Alejandro, and Bruce Preston (2010b) Monetary policy and uncertainty in an empirical small open-economy model Journal of Applied Econometrics 25:1, 93-128.

Lubik, Thomas, and Frank Schorfheide (2005) A Bayesian Look at New Open Economy Macroeconomics. In NBER Macroeconomics Annual, 2005, edited by Ben S. Bernanke and Kenneth Rogoff, pp. 313-366.

Lubik, Thomas, and Frank Schorfheide (2007) Do central banks respond to exchange rate movements? A structural investigation. Journal of Monetary Economics 54:4, 1069-1087.

Newey, Whitney K. and Kenneth D. West (1987) A Simple, Positive Semi-definite, Heteroskedasticity and Autocorrelation Consistent Covariance Matrix. Econometrica $55: 3,703-08$.

Obstfeld, Maurice, and Kenneth Rogoff (1995) Exchange Rate Dynamics Redux. Journal of Political Economy 103, 624-660.

Obstfeld, Maurice, and Kenneth Rogoff (2005) Global Current Account Imbalances and Exchange Rate Adjustments. In Brookings Papers on Economic Activity, 
2005 Vol. 1, edited by William Brainard and George Perry, pp. 67-146.

Povoledo, Laura (2010) The Volatility of the Tradeable and Nontradeable Sectors: Theory and Evidence. MPRA Paper 14852, University Library of Munich, Germany.

Rabanal, Pau, and Vicente Tuesta (2010) Euro-dollar real exchange rate dynamics in an estimated two-country model: An assessment. Journal of Economic Dynamics and Control 34:4, 780-797.

Rogerson, Richard (1988) Recursive Competitive Equilibrium in Multi-Sector Economies. International Economic Review 29:3, 419-430.

Uhlig, Harald (1999) A Toolkit for Analizing Nonlinear Dynamic Stochastic Models Easily. In Ramon Marimon and Andrew Scott (eds.), Computational Methods for the Study of Dynamic Economies, pp. 30-61. Oxford: Oxford University Press. 
Table 1: Parametrization

\begin{tabular}{llc}
\hline \hline & Description & Value \\
\hline$\beta$ & Discount factor & 0.99 \\
$\nu$ & Financial intermediation cost & 0.0005 \\
$\gamma$ & Weight of nontradeable goods in total consumption & 0.665 \\
$\theta$ & Elasticity of substitution Home-Foreign tradeables & 2 \\
$\delta$ & Weight of Foreign goods in Home tradeable consumption & 0.33 \\
$\delta^{*}$ & Weight of Foreign goods in Foreign tradeable consumption & 0.67 \\
$\eta_{T}$ & Elasticity of substitution among tradeable goods & 7.67 \\
$\eta_{N}$ & Elasticity of substitution among nontradeable goods & 4.58 \\
$\zeta$ & Pass-through elasticity for Home imports & 0.23 \\
$\zeta^{*}$ & Pass-through elasticity for Foreign imports & 0.4787 \\
$\varphi_{T}, \varphi_{N}$ & Probabilities of not changing prices (Home and Foreign) & 0.75 \\
$\alpha_{T}$ & Elasticity of output with respect to hours (tradeables) & 0.7364 \\
$\alpha_{N}$ & Elasticity of output with respect to hours (nontradeables) & 0.7218 \\
\hline \hline
\end{tabular}


Table 2: GMM estimates

\begin{tabular}{clc}
\hline \hline & Description & Estimate \\
$\sigma$ & Elasticity of marginal utility of real money balances & 2.3044 \\
$\phi$ & Risk aversion for consumption & 6.3679 \\
\hline & Elasticity of substitution tradeable-nontradeables & 0.6648 \\
\hline Exogenous processes: $\widehat{x}_{j, t}=\rho_{j} \cdot \widehat{x}_{j, t-1}+\epsilon_{j}$ & \\
\hline$\rho_{j}$ & AR coefficient Home nominal money growth & 0.4441 \\
& AR coefficient Home tradeable technology & 0.8321 \\
& AR coefficient Home nontradeable technology & 0.8045 \\
& AR coefficient Home government expenditure & 0.6774 \\
& AR coefficient Foreign nominal money growth & 0.3494 \\
& AR coefficient Foreign tradeable technology & 0.8374 \\
& AR coefficient Foreign nontradeable technology & 0.5852 \\
& AR coefficient Foreign government expenditure & 0.6462 \\
\hline Var $\left(\epsilon_{j}\right)$ & Variance Home nominal money growth & $8.50 \cdot 10^{-5}$ \\
& Variance Home tradeable technology & $6.52 \cdot 10^{-5}$ \\
& Variance Home nontradeable technology & $1.17 \cdot 10^{-5}$ \\
& Variance Home government expenditure & $1.55 \cdot 10^{-6}$ \\
& Variance Foreign nominal money growth & $6.36 \cdot 10^{-5}$ \\
& Variance Foreign tradeable technology & $9.24 \cdot 10^{-5}$ \\
& Variance Foreign nontradeable technology & $2.14 \cdot 10^{-5}$ \\
& Variance Foreign government expenditure & $2.20 \cdot 10^{-6}$ \\
\hline \hline & Cov(Home nom. money growth, Home nontrad. prod.) & $1.21 \cdot 10^{-5}$ \\
Cov(Home nom. money growth, Home gov. exp.) & $2.29 \cdot 10^{-6}$ \\
Cov(Home nom. money growth, Foreign trad. prod.) & $-3.25 \cdot 10^{-5}$ \\
Cov(Home nom. money growth, Foreign gov. exp.) & $-2.19 \cdot 10^{-6}$ \\
Cov(Home trad. prod., Foreign trad. prod.) & $3.14 \cdot 10^{-5}$ \\
Cov(Home nontrad. prod., Home gov. exp.) & $2.52 \cdot 10^{-6}$ \\
Cov(Home nontrad. prod., Foreign trad. prod.) & $-8.59 \cdot 10^{-6}$ \\
Cov(Home gov. exp., Foreign trad. prod.) & $-2.46 \cdot 10^{-6}$ \\
Cov(Foreign trad. prod., Foreign nontrad. prod.) & $1.76 \cdot 10^{-5}$ \\
Cov(Foreign nontrad. prod., Foreign gov. exp.) & $-1.12 \cdot 10^{-6}$ \\
\hline \multirow{2}{*}{ Cov $\left(\epsilon_{j}, \epsilon_{j}^{\prime}\right)$} & \\
& &
\end{tabular}


Table 3: Business cycle statistics

\begin{tabular}{|l|c|c|c|c|}
\hline \hline \multirow{2}{*}{} & \multicolumn{2}{|c|}{$\begin{array}{c}\text { Standard deviations } \\
\text { relative to GDP }\end{array}$} & \multicolumn{2}{c}{ Autocorrelations } \\
\cline { 2 - 5 } & Data & Model & Data & Model \\
\hline Consumption & 0.77 & 0.46 & 0.84 & 0.63 \\
Employment & 0.68 & 1.60 & 0.86 & 0.63 \\
Net exports & 0.13 & 0.12 & 0.95 & 0.55 \\
Real exchange rate & 4.86 & 2.97 & 0.82 & 0.61 \\
Nominal exchange rate & 4.78 & 4.22 & 0.82 & 0.68 \\
\hline \hline
\end{tabular}

Note: The statistics are based on logged and H-P-filtered data. With the exception of net exports, all standard deviations are divided by the standard deviation of output. Data sources: Net exports are the HP-filtered ratio (with US GDP as the denominator) of net exports to France, Germany, Canada, Japan, Mexico and the UK, computed using BEA data. The foreign price index (used in the calculation of the real exchange rate) and the nominal exchange rate are, respectively, the geometric weighted averages of the OECD CPI indexes and IMF exchange rates for France, Germany, Canada, Japan, Mexico and the UK. All the remaining data variables are from the OECD.

Table 4: Data moments

\begin{tabular}{|c|c|c|c|c|c|c|c|c|}
\hline & \multirow{2}{*}{$\begin{array}{l}\% \text { st } \\
\text { dev }\end{array}$} & \multirow{2}{*}{$\begin{array}{l}1-\mathrm{st} \\
\mathrm{AC}\end{array}$} & \multicolumn{6}{|c|}{ Correlogram } \\
\hline & & & $\pi_{T H}^{T o t}$ & $\pi_{N}$ & $\widehat{Y}_{T H}^{T o t}$ & $\widehat{Y}_{N}$ & $\widehat{n}_{T H}$ & $\widehat{n}_{N}$ \\
\hline$\pi_{T H}^{T o t}$ - Home tradeable inflation & 0.83 & 0.14 & 1.00 & & & & & \\
\hline$\pi_{N}$ - Home nontradeable inflation & 0.45 & 0.32 & 0.14 & 1.00 & & & & \\
\hline$\widehat{Y}_{T H}^{T o t}$ - Home tradeable output & 2.50 & 0.86 & 0.32 & 0.44 & 1.00 & & & \\
\hline$Y_{N}$ - Home nontradeable output & 0.50 & 0.80 & 0.14 & 0.15 & 0.34 & 1.00 & & \\
\hline$\widehat{n}_{T H}$ - Home tradeable employment & 1.98 & 0.91 & 0.20 & 0.55 & 0.85 & 0.29 & 1.00 & \\
\hline$\widehat{n}_{N}$ - Home nontradeable employment & 0.89 & 0.94 & 0.27 & 0.53 & 0.69 & 0.49 & 0.87 & 1.00 \\
\hline
\end{tabular}

Note: Data sources and definitions are available from the author on request. Statistics were computed using logged and HP-filtered prices, output and employment levels. 
Table 5: Model moments

\begin{tabular}{|l|c|c|c|c|c|c|c|c|}
\hline \hline & \% st & \multicolumn{1}{|c|}{ 1-st } & \multicolumn{6}{|c}{ Correlogram } \\
& dev & AC & $\pi_{T H}^{T o t}$ & $\pi_{N}$ & $\widehat{Y}_{T H}^{T o t}$ & $\widehat{Y}_{N}$ & $\widehat{n}_{T H}$ & $\widehat{n}_{N}$ \\
\hline$\pi_{T H}^{T o t}$ - Home tradeable inflation & 0.52 & 0.18 & 1.00 & & & & & \\
$\pi_{N}$ - Home nontradeable inflation & 0.32 & 0.64 & 0.79 & 1.00 & & & & \\
$\widehat{Y}_{T H}^{T o t}$ - Home tradeable output & 0.88 & 0.67 & 0.75 & 0.89 & 1.00 & & & \\
$\widehat{Y}_{N}$ - Home nontradeable output & 0.39 & 0.62 & 0.73 & 0.88 & 0.85 & 1.00 & & \\
$\widehat{n}_{T H}$ - Home tradeable employment & 1.68 & 0.63 & 0.66 & 0.64 & 0.65 & 0.65 & 1.00 & \\
$\widehat{n}_{N}$ - Home nontradeable employment & 0.50 & 0.63 & 0.42 & 0.63 & 0.51 & 0.43 & 0.41 & 1.00 \\
\hline \hline
\end{tabular}

Note: Statistics are averages over 100 simulations, each of length 111, after the first 1,000 observations were discarded. Statistics were computed using logged and HP-filtered variables. The model parameters are those of Tables 1 and 2 .

Table 6: Sensitivity analysis

\begin{tabular}{|c|c|c|c|c|c|c|}
\hline & \multicolumn{6}{|c|}{ Variables, Percent standard deviations } \\
\hline & $\pi_{T H}^{T o t}$ & $\pi_{N}$ & $\widehat{Y}_{T H}^{T o t}$ & $\widehat{Y}_{N}$ & $\widehat{n}_{T H}$ & $\widehat{n}_{N}$ \\
\hline$\theta=1$ & 0.50 & 0.32 & 0.53 & 0.38 & 1.42 & 0.49 \\
\hline$\delta=1-\delta^{*}=0.40$ & 0.58 & 0.33 & 0.96 & 0.41 & 1.75 & 0.52 \\
\hline$\varphi_{T}=0.6$ & 0.69 & 0.33 & 0.82 & 0.48 & 1.49 & 0.58 \\
\hline Local currency pricing & 0.77 & 0.32 & 0.38 & 0.37 & 1.27 & 0.48 \\
\hline Producer currency pricing & 0.33 & 0.33 & 1.87 & 0.47 & 2.78 & 0.58 \\
\hline Complete markets & 0.74 & 0.30 & 1.66 & 0.43 & 2.53 & 0.55 \\
\hline $\begin{array}{l}\text { Corr }(\text { Home tradeable and nontr. prod. })= \\
=\text { Corr }(\text { Foreign tradeable and nontr. prod. })=1\end{array}$ & 0.52 & 0.33 & 0.88 & 0.37 & 1.65 & 0.75 \\
\hline
\end{tabular}

Note: The calibration of the model differs from Table 5 only with respect to the parameters indicated in each row. In the last row, I assume that technology shocks are perfectly correlated domestically and uncorrelated with the other shocks. Statistics are computed as averages over simulations. 